\title{
The Protection of Human Rights in Post-Communist Albania
}

\author{
Meljana Bregu \\ University of Tirana
}

\section{Abstract}

\begin{abstract}
Albania was one of the most isolated countries in Europe for nearly 45 years. During the communist era, the legal system was under the direct control of the Party of Labor. The protection of human rights in the first years of the communist regime was clearly shaped on the soviet principles. The criminal code of Albania was the symbol of a repressive system, regardless of human rights protection, crimes punishable by death were sanctioned by various articles, including "agitation and propaganda against the state" and 'activities against the revolutionary movement of the working class". Hoxha also closed the Ministry of Justice and banned the private practice of law as a consequence the right to a fair trial was denied. After the fall of communism Albania has made significant progress toward respect for civil and political rights, especially toward the right to a fair trial. The constitution of 1998 protects the right to a fair trial in chapter two and one important step is the ratification of the European Convention on Human Rights in 1996, which guarantee the right to a fair trial in article six. Still, 25 years of transformation are not enough to wipe away the legacy of the past; the lack of human rights mechanisms poses a serious challenge to the Albanian democratic system. Still today Albania faces important issues concerning the protection of human rights generally and particularly the right to a fair trial. This fact is evident if we refer to the cases of the European Court of human rights versus Albania dealing with the application of article 6 of the Convention.The paper aims to address the protection of human rights after the demise of the communist regime, especially regarding the right to a fair trail, analyzing the progress but also the continuity in some aspects with the past.
\end{abstract}

Keywords: democracy, human rights, the right to a fair trial, transition

\section{Introduction: Human rights in communist Albania}

The universality of human rights is based on the apprehension that if all humans are equal, then the rights that they have as a consequence of being human are the same regardless of the culture into which the individual happens to be born. This is the fundamental justification for the ideals expressed internationally in the oeuvre of the Council of Europe that dominated the visual sense of the Western countries after the Second World War and was fixed as western liberal thought, without value outside the western context (Sweeney, 2014, 460)

Alternatively, during the cold war, relativism - a cautious view of public international law that affords greater respect for state sovereignty - dominated socialist public international legal philosophy. Thus, human rights were treated as an aspect of domestic jurisdiction and a policy of non-interference was promoted. Due to relativism the values promoted by the system are relative only to the society from which they are derived and are incapable for universality. From a relativistic point of view it's unjustifiable to impose upon one society a system of social justice deriving from another, including in this even human rights system, imposing serious problems for their protection.

Referable to the relativistic view Albania was insensitive to the norm of international law and its application into the intern legal system. Many quotes by the UN Commission on Human Rights and the Sub-Commission on prevention of discrimination and Protection of Minorities have not laid in any change and improvement in human rights protection. Albania was cited repeatedly for its treatment of minority citizens, particularly the Greeks and for its stringent anti-religious policies when in 1967 became the world's first atheist country (Lawson, Bertucci, 1996, 45).

The protection of human rights is not a consolidated practice or tradition in Albania, its origins dated back only in the late 20's. Hence the Soviet practice borrowed from Mosca after the Second World War caused its own dynamics. The soviet model was not connected with Albanian tradition and necessities. According to the Marx theory applied in the socialist 
countries, including Albania, law in a socialist state must be nothing more than the imposition of dominating class - the working class - over the bourgeoisie. Thus, values as individual rights and equality before the law were considered as fraudulent masks worn by the bourgeoisie for economic supremacy and exploitation (Zimmerman, 2009). All the values of liberal democratic societies were denounced as merely being ideological tools for legitimizing an exploitive economic system that would serve only the dominant economic group (Zimmerman, 2011, 22).

Communism in its Leninist interpretation was inimical to the values of individual rights and human freedom, which were an obstacle for the revolution and for the win of the proletariat against the bourgeoisie (Lenin, 1952, 226). Enver Hoxha, who was an ardent disciple of the Soviet Union at the time, strongly claimed in his official speeches that the proletariat detains the power and all the bourgeoisie concepts and elements of human rights and liberties had to disappear from the new communist society. The first Albanian constitution of 1946 which defines Albania a People's Republic did not cite the people as subjects of law and rights, but the Albanian workers (Gjykata e Larte, 1975, 6). The latter on the approval of the fundamental law in 1952 the judicial system was reformed with the approval of a new penal code. The penal code was different in the Hoxha words from any other penal code applied in capitalist countries and bourgeoisie systems (Hoxha, 1952, 481).

Indeed, the penal code was different it provided the capital punishment in several articles, for offenses against the state which included leaving the country without permission, crimes against life, etc. The penal code included a raw character of criminal offense defined as agitation and propaganda against the popular power which mean calls to undermine or subvert the people's power and the preparation, dissemination or preservation for dissemination of writings with such content, are sentenced: by deprivation of liberty from three to ten years. When these acts are committed in time of war or have particularly serious consequences, are punished by deprivation of liberty of not less than ten years or by death with confiscation of property anytime (article 73).

According to Gonenc the characteristics of the socialist conception of human rights are three and they present with a different shape in almost all of socialist countries. First, the possession and enjoyment of human rights and liberties must not obstruct the realization of the ultimate goal, a classless society (Gonenc, 2002, 221). Freedom of association provides a well-defined case of this. According to the 55 article of the Albanian constitution of 1976 - which modify the constitution of 1946 - the freedom of organization was permitted in accordance with the aims of the communist system, indeed were not permitted the religious organizations, anti-democratic organizations and anti socialist organizations.

Second the socialist conception of human rights gave prominence not to the individual but to the state. This provided the full control of the state over the creation and application of rights and liberties. Two are the aspects of the centrality of the state in human rights that can emphasize. On the one hand the state was the only source of human rights. On this way the rights and the liberties were granted by the state and could be taken away from it (Gonenc, 2002, 221). Rights and liberties were not inalienable in a communist regime in contrast to the liberal one (Mezzetti, 2010,20). A clear case is the Albanian constitution of 1976 that defines Albania a People Socialist Republic, according to which: The rights and duties of citizens are built on the basis of the reconciliation of the individual interests and of the socialist society, giving priority to the general interest. The rights of the citizens are inseparable from the fulfillment of their duties and cannot be exercised in opposition to the socialist order. The further extension and deepening of the rights of citizens are closely linked with the socialist development of the country. (Art. 39)

Third the socialist concept of human rights in the Albanian constitution finds inspiration in the socioeconomic premises of Marxism-Leninism. The fusion of rights and duties, the primacy of economic and social rights over civil liberties and political rights, the ban on individual ownership of the means of production, the importance of the right to work and the accent on equal rights were the reflection of Marxism-Leninism principles (Gonenc, 2002, 222).

The second section of the constitution was centered along the economic order and especially the 16th article define the economic system of the People's Socialist Republic as a socialist economy based on the socialist ownership of the means of production and the second comma of the article proihibited private property.

The human rights in Albania during the communist regime were systematically violated; a serious violation was the denial of the right to a fair trial. The right to a fair trial was violated by the complete absence of independent courts and by the denial of the right to defense. Institutionally in 1966 was disbanded the Ministry of Justice and was eliminated the part of 
the defense attorney. The elimination of the defense lawyer role in a state where didn't exist the freedom of speech transformed the right to a fair trial in an empty phrase. Albanian citizens were plagued by serious human rights violation such as restriction of freedom of expression and association, manipulation of the legal system and violence by the police. The numerous branch of human rights the dishuman treatment of the prisoners, especially of the politic prisoners, many of whom died in the communist prisons are not the main focus of the paper, but this brief introduction puts light on the problems that Albania faced aftermath the demise of the communist regime.

\section{The constitutional reform and international instruments for the protection of human rights after the demise of communist regime}

The downfall of the communist regime marked the end of almost half a century of dictatorship and inaugurated a new era, a period of intense changes started to reshape the political and institutional view of Albania. Albania faced the daunting challenge of having to reconstruct almost every single aspect of its system in very little time in order to avoid more havoc and to keep some stability but it was the communist country less prepared for these changes. For nearly a half century experienced a brand of communism unknown to the rest of Eastern Europe, isolationism and dictatorship kept the country as the poorest and most repressive of all Europe.

The student protest of 1990 was a promoter of democratic changes in Albania. In 1991 were held the first pluralist elections and various reforms have taken place on a number of levels. The main reform was concentrated on the constitution, with a new set of constitutional provisions in force until the enactment of the new Constitution in 1998 which guarantee to Albania the status of a parliamentary democracy. The human rights protection was at the time a main topic of concern for the political elite. Article 2 of the Constitutional act states: The dignity of man, his rights and freedoms, the free development of his personality, the constitutional order, equality before the law, social justice, and the multi-party system constitutes the foundation of the State which has an obligation to respect and protect them. Thus, several amendments were made to the legislation and one positive step was the abolition of death penalty for woman and persons under the age of 18 , the reintroduction of conditional release, the reintroduction of the counsel and other criminal procedures (Lawson, 1996, 46). The problem of capital punishment was not at the core of the new government attention despite the incontrovertible fact of the abolition of death penalty for adult female. Indeed a crucial role in the abolition of capital punishment had the efforts of Albania to be a member of the Council of Europe. The Council of Europe, explicitly tied the question of Albania's membership to its progress on human rights issues, particularly the abolition of the death penalty (Frankowski, 1996, 230). In 1995 Albania signed a declaration stating that will sign, ratify and apply Protocol n. 6 of the European Convention on Human Rights on the abolition of the death penalty in time of peace within three years. Indeed, from 1995 Albania puts into place a moratorium on executions and ratified the Protocol in 2000 when the capital punishment was definitely abolished.

Despite these positive changes, of especial note were the laws on foreign investment, land reform and the right of former political prisoners, many problems continue. For instance the new penal code of 1995 had been criticized by the Albanian Helsinki Committee - local human rights group - for the high number of crimes punishable by death as well as the harshness of punishment contained in the code (Human Rights Watch Helsinki, 39, 1996).

Another important problem was the rights to a fair trail. The constitutional law on Fundamental Rights and Freedoms protected an individual's right to a fair trial. Article 7 to 13 had guaranteed the presumption of innocence, access to a lawyer of one's choice and sufficient time and facilities to prepare a defense also the law enhance the right to a fair, quick and public trial by a competent, impartial and independent court (Art. 40). Despite this legal guarantee, Human Watch Rights Watch Helsinki has documented various and numerous violations of due process. Defendants were often held in pretrial detention beyond the maximum time allowed, denied access to a lawyer and sometimes subjected to physical or psychological abuse while in police custody (Abrahams, 1996, 41). The violations were due to the police force and judiciary inexperience with the new legal order, and an incomplete break with the practice of totalitarian regimes. A focal point was also the ill-treatment and the excessive utilization of violence by police and prison guards. An obvious example of this phenomenon was given in the report of Amnesty International "Albania" who received over one hundred complaints about the unlawful use of force from 1994 to 1995 (Amnesty International, 1995). The situation described below is a general panorama of the violations of human rights despite the legal framework and the international conventions ratified from Albania aftermath the fall of communism. The problem in this period from 1992 to 2000 was not the lack of the legislative instruments, but the substantial defense of the human liberties and the implementation of the legal framework. In many 
cases the authors of the violations, especially in ill-treatment case and torture by the guard in person remain unpunished and not responsible for their action. This got to a little faith of the Albanian citizens in the criminal justice system.

Analyzing the material rules of the protection of human rights a huge step toward was the adoption of the Constitution of the Republic of Albania 1998. The constitution was adopted by popular referendum and drafted with assistance of the Venice Commission, guarantees the rights, freedoms and duties of all persons within and subject to the jurisdiction of the Albanian state. The main achievement lies in a more innovative and precise regulation of basic legal and institutional norms at the constitutional level (Bianku, 2016, 14). Part II of the constitution is dedicated to human rights and freedoms which are arranged in six chapters, but the most important is the second chapter which provides for personal rights and freedoms. Among the values of the new Constitution is first, the Preamble, which stresses that the Constitution is made aside the people of Albania with faith in God to build a popular and social state based on the rule of law and to ensure the fundamental human rights and freedoms with a life of tolerance and religious coexistence. The constitution envisages the faith in god and the religious coexistence among the three religions after almost 40 years after the definition of Albania as an atheist state. The text stipulates also a fundamental principle in Part 1, the basis of the Albanian state is the dignity of the person his rights and freedoms, and the state is bound to protect and respect them.

The second section of the Constitution is devoted to fundamental human rights and freedoms. The first chapter provides the universal principles of the human rights and freedoms and qualifies them as inalienable, inviolable and inseparable. The second and most important chapter defines the personal freedoms and rights, guarantee the freedom of speech, the freedom of religion, the right to a fair trail, the private property, etc.

The third chapter is devoted to political rights and freedoms which guarantee the right of assembly and the fourth chapter comprises economic, societal and cultural rights. The fifth chapter focuses on the social objectives such as more equitable education, improved sanitation, employment and health care. The sixth chapter provides the principles governing the office of the Ombudsman.

Beside the constitutional act of 1992 and the constitution of the 1998 the protection of human rights is not thorough by material rules, hence the law considered in terms of reference relating international instrument that enrich the catalogue of constitutional rights; or accept international rules as interpretative parameters. The catalogue of constitutional rights mentioned in the law of 1993 was enriched in other acts drafted in conformity with the international Convention on human rights. Albania has ratified the major international human rights instruments such as the International Covenant on Civil and Political Rights, the International Convention on the Elimination of all forms of racial discrimination and the Convention against Torture and other Cruel, Inhuman or Degrading Treatment or Punishment (Abrahams, 1996).

In the mentioned context due to the phenomena of law importation that took place non only in Albania but also in the other countries of Eastern Europe the main term of reference regarding the protection of human rights is the European Convention of Human Rights the most prominent human treaty promoted by the Council of Europe. Albania became a member of the Council of Europe in 1995 and in the same date ratified the European Convention on Human Rights and recognized the competence of the European Court of Human Rights. Referable to the Constitution of 1998 the international agreements have normative effects in the domestic legal sphere by virtue of their ratification, art. 116 provide that normative acts effective in the entire territory of the Republic of Albania are the Constitution, the ratified international agreements, the laws and normative acts of the Council of Ministers. Due to article 122 - an international agreement ratified by law has priority over the laws of the country that are incompatible with it - an international ratified treaty is second only to the Constitution inside to the Albanian legal system. Agree to this article in case of incompatibility between a ratified international agreement and an ordinary domestic law, the international treaty norm will prevail (Bianku, 16).

The European Court of Human Rights has received various applications from Albanian citizens. The 495 applications lodged against Albania concern largely on the non enforcement of the domestic decisions, the right to a peaceful joy of the property, the right to a fair trail and the conditions of pre-trial detention (Bianku, 19). The applications concerning Albania bring to light the major problems of the judicial system in Albania.

Selected Examples - Cases related to Article 6 of the Convention - violation of the right to a fair trial

In Laska and Lika v. Albania - (N. 319.20/04/2010) 
A fair and public hearing art. 6 comma 1 - In 2001 Mr. Lika and Laska were charged with armed robbery and illegal possessions of arms which they contested before the district court. The court noticed certain irregularities during the investigation stage, such as the absence of the layer both during the questioning and the identification, but it found the applicants guilty on the basis of the eyewitness statements. During the identification and the questioning conducted by the police officers in charge the layer of the applicants was not present. The Court observed that even the District Court had admitted that there had been irregularities at the investigation stage, in convicting the applicants it had relied to the outcome of the investigation stage. Besides the Court considers that the patent disregard of the rights of the defense at this stage seriously undermined the fairness of the subsequent criminal trial. Consequently the proceedings in question had been unfair in violation of Article 6 .

\section{In Driza v. Albania and Ramadhi and other versus Albania (n. $\underline{33771 / 02)}$}

The court recommended to Albania to take urgent measures in restitution of property cases. These two cases are related to two problematic aspects of the protection of human rights, the right to a fair hearing and the protection of the property. The cases concerned the non-enforcement of assessments and administrative decisions in restitution of property cases, a widespread problem involving large numbers of people in Albania. In both cases the applicants took legal action to regain ownership of property belonging to their fathers, which had been removed by the authorities without payment of recompense. The Court concluded that there had been a violation of Article $6 \S 1$ in respect of the breach of the principle of legal certainty, the impartiality of the court and the non-enforcement of a final judgment. Granting to the Court, in granting leave to receive a final judgment reviewed and allowing the insertion of parallel sets of transactions, the Albanian Supreme Court had put at naught an entire judicial process which had terminated in a final and enforceable judicial decision.

The violations of article 6 , article 13 , and the violation of the security of the property reflected a widespread trouble in Albania and the European Court imposed an obligation on the Albanian state to address this problem. It held that Albania had to take general measures in order to effectively secure the right to compensation within 18 months from the date in which the judgement became final. The emblematic case law was Manushaqe Puto and Others v. Albania (applications N. $604 / 07,43628 / 07,46684 / 07$, and 34770/09) in which human right judges awarded 680.000 euro against Albania following a complaint against the country's failure to enforce compensation rulings. According to the facts 20 applicants complained that, despite their inherited title to plots of land is recognized by the authorities, the final administrative decisions awarding them compensation in lieu of restitution had never been enforced. They relied on article 13 of the Convention which has focused on the lack of effective remedies in relation to article 6 of the convention and Article 1 of the First Protocol. In relation with article 13 the Court concluded that the impossibility to have an effective form of compensation provided by law proved that there was no effective domestic remedy on account of the prolonged non-enforcement of administrative decision awarding compensation. The Court found violations of article 6 in relation to the lack of effective remedies in relation to the length of proceedings. The length of the proceeding was faced by the Court in Mishgjoni case explained abovel

Right to a fair hearing with a reasonable time - Mishgjoni versus Albania (2010)

The judgment dealt with the proceedings in the case of Mirela Mishgjoni whom complaints about the excessive length of proceedings with regard to her dismissal in 2002 from her post as a district court judge. After ruling on the applicability of the article 6 in proceedings concerning the applicant's dismissal as a judge, the Court found that the duration of the dismissal proceedings by the High Court of Justice did not satisfy the reasonable time requirement under the Convention (Bianku, 22). Also, in 2014 in another similar case (Luli and others v. Albania - 64480/09) the Court finds the length of proceedings to excessive and indicate that the Albanian authorities should undertake general measures in relation of this problem. The Court recalls that it is for the Contracting States to organize their legal systems in such a way that the competent authorities can meet the requirements of Article 6 of the Convention.

This few example are symptomatic of the same problems of the Albanian judiciary system, the length of the proceedings, the access to the justice system, the non-enforcement of court decisions has brought to a loss of faith on the justice in Albanian citizens, whom perceive the system as corrupted and ineffective. This is discernible also in the EU's Progress Report on Albania, of October 2014, the functioning of the judicial system continues to be affected by politicization, limited accountability, poor interinstitutional cooperation, while claims of corruption inside the justice system remain a grave worry. Based on a study by IDRA, which focused on citizens' perception of the judiciary, it results that $84 \%$ of those polled think 
that judges are not impartial in Albania, thus expressing the profound crisis of credibility in them (Impunity - Perceptions and experiences of Albanian Citizens 2014-2015). The bad functioning of the judicial system is a crucial point which seems to reflect not only the economic situation of the country but also the legacy of the past. In this situation the justice reform approved in July 2016 by the Parlament was necessary, but the implementation has not yet begun.

The legal framework for the protection of human rights is broadly in line with the European standards. Nevertheless, implementation is limited and enforcement of human rights remains insufficient. There is a large gap between human rights protection that citizens should have in theory and how individuals or groups experience the protection of their rights in reality. On this regard Civil Right Difenders - an independent expert organization - in its report found that human rights continued to be breached in Albania. Agreeing to this report, the treatment of vulnerable groups is extremely problematic in Albania. Discriminatory attitudes and practices prevail against the Roma/Egyptians and LGBT communities. Independent institutions, such as the Office of Ombudsman, despite the active engagement have had only limited impact when it comes to improving human rights. Widespread corruption and impunity are a contributing element in the country's poor human rights record (Human Rights in Albania, Country Report, 2015).

In 2014 the EU candidate status was granted to Albania, thus marking an important step toward European integration. The EU has identified the protection of human rights as one of the five priorities Aereas. Although in 2015 the EU values the positive efforts in the enforcement of human rights in Albania but affirms that the capability of institutions in charge of the protection and enforcement of human rights remains weak, and there is a particular demand for more well-trained, specialist staff in the judiciary and police (Albania, 2015 report). The most problematic area remains the disproportionate role of force and violence by police officers and prison guards and the overcrowding of the prison system. Also more efforts are needed to implement the strategy on property rights, to complete the process of registering properties, to ensure enforcement of the judicial decisions and to continue the process of restitution and compensation. Another problematic aspect of human rights in Albania has to come to light, specifically the protection of minorities and the integration of the Roma community. Roma and Egyptians continue to face difficult living conditions, frequent social exclusion and discrimination, especially regarding access to wellness care, social security, training, work and lodging. Albania faces problems also with the integration of persons with disabilities, and the discrimination of LGBT community. Besides in these years domestic violence against women is a serious problem and the country does not have enough mechanisms to address gender-based violence. Protection Orders are often violated and the number of female murders is still high.

This paper does not address the full scope of human rights and freedoms sanctioned by the Constitution and international acts, applicable in the Republic of Albania. The paper looked and addresses part of them, especially the right to a fair trial and the evolution of the human rights situation in Albania since the fall of the communist regime. Since the fall of the communist regime the situation is improved, the legal framework is more complete and the state is more sensitive to the complaints of citizens. Although these positive changes are not enough to warrant a complete protection of human rights in Albania especially for weak and marginalized groups like woman, children, Roma community and the captives. The lack of faith in the justice system and often the malfunction of it remain a point of great concern. At this point the efforts of all the actors like state and ONG are necessary but not enough, a focal node is the participation of the citizens. Relying on the IDRA report mentioned above, although corruption, breaking of the law and impunity are seen as big problems, very few citizens claim to have engaged in any activities to report these phenomena. Only a small number of citizens signed petitions, wrote on specific case of corruption in social media or demonstrate against this phenomena. The economic situation and the slow development also the lack of the efforts of all the citizens, state, and civil society brings to poor result human rights record despite a general improvement of the protection of human rights from the demise of communist till to the new justice reform.

\section{BIBLIOGRAPHY}

[1] Abrahams F. and Human Rights Watch Helsinki (ed). 1996. Human Rights in post - communist Albania, USA

[2] Amnesty International. (ed). 1995 Albania: failure to end police ill-treatment and deaths in custody. Index number Index number: EUR 11/004/1995 retrieved from https://www.amnesty.org/en/documents/eur11/004/1995/en/ 
[3] Bianku, L. in Motoc I. and Ziemele I. (Ed) 2016. Albania long path toward European Human Rights standards in The impact of the ECHR on Democratic change in central and eastern Europe, Cambridge.

[4] Driza v. Albania and Ramadhi and others v. Albania. European Court of Human Rights N. 33771/02, N. 38222/02 retrieved from http://hudoc.echr.coe.int/

[5] European Commission. 2015. Albania Progress Report retrieved in

[6] http://ec.europa.eu/enlargement/pdf/key_documents/2015/20151110_report_albania.pdf

[7] Frankowski S. (ed). 1996. Capital Punishment, global issue and prospects, Winchester

[8] Gonenc L. (ed). 2002. Prospects for Constitutionalism in Post-Communist Countries, Hague

[9] http://www.gjykataelarte.gov.al/web/kushtetuta_e_republikes_se_shqiperise_1298.pdf - Albania Constitution

[10] Gjykata e Larte e RPSH. (ed). 1975. Zhvillimi i legjislacionit socialist ne RPSH.Tirane, 8 Nentori

[11] Hoxha, E. (ed). 1952. Vepra, vellimi 4. Tirane

[12] Human Rights in Albania. 2015. Country Report retrieved from https://www.civilrightsdefenders.org/countryreports/human-rights-in-albanial

[13] Impunity - Perceptions and experiences of Albanian Citizens (2014-2015) retrieved from http://www.idracompany.com/

[14] Lawson Edwards. (ed) 1996. Encyclopedia of Human Rights, Washington

[15] Laska and Lika versus Albania. European Court of Human Rights. N. 319. 20/04/2010 retrieved from http://hudoc.echr.coe.int/

[16] Lenin. (ed). 1952. Vepra, vellimi 32. Tirane

[17] Mezzetti, L. (ed). 2010. Human Rights. Bologna: Bonomia

[18] Sweeney A. James. (ed). 2014. Margins of Appreciation: Cultural Relativity and the European Court of Human Rights in the post-cold era. International and Comparative Law Quaterly retrieved from http://www.pierrelegrand.com/sweeny.pdf

[19] Zimmerman A. (ed). 2009. Marxism, Law and Evolution retrieved from http://creation.com/marxism-law-andevolution

[20] Zimmerman Augusto. (ed) 2011. Marxism, Communis and Law: How Marxism led to lawlessness and genocide in the former Soviet Union in The Western Australian Jurist N.60, 